\title{
NUTRITIONAL PROFILE AND ITS CORRELATION WITH THE MAIN PROGNOSTIC FACTORS IN WOMEN WITH BREAST CANCER UNDERGOING SURGICAL TREATMENT
}

\author{
Perfil nutricional e sua correlação com os principais fatores prognósticos \\ em mulheres com câncer de mama submetidas a tratamento cirúrgico
}

\author{
Tamires Regina da Silva Cunha ${ }^{1 *}$, Isabel Cristina de Almeida Santiago', Rachel Souza Thompson Motta
}

\section{ABSTRACT}

Objective: To analyze the association of nutritional status and fasting blood glucose with the main tumor prognostic factors in invasive breast cancer in women undergoing surgical treatment. Methods: Retrospective study with women aged 18 years or older, diagnosed with invasive breast cancer, admitted for surgical treatment at Cancer Hospital III - National Cancer Institute José Alencar Gomes da Silva. The variables collected were: age, Body Mass Index (BMI), comorbidities (hypertension and diabetes mellitus), neoadjuvant chemotherapy, menopausal status, fasting blood glucose, clinical staging, and tumor markers (estrogen and progesterone receptor/HER2/Ki-67). Categorical data were expressed by frequency and percentage, and numerical data by mean and standard deviation. We used the following tests to perform the statistical analysis: Kruskal-Wallis, Mann-Whitney, Pearson's $x^{2}$, and Spearman tests. P-values $<0.05$ were considered statistically significant. Results: 166 patients participated in thestudy. The meanage was 59.1 ( \pm 12.4$)$ years, and the mean fasting blood glucosewas $109.5 \pm 23.7 \mathrm{mg} / \mathrm{dL}$. According to BMl, $62.1 \%$ of the sample was overweight. The high BMI was related to hypertension and hyperglycemia, and no association with prognostic factors was found. Hyperglycemia was associated with more advanced age, higher lymph node involvement, hormone receptor positive, and post-menopausal status. Conclusion: The nutritional status classified by BMI was not related to prognostic factors in breast cancer, suggesting the need for other complementary anthropometric methods for better nutritional diagnosis. KEYWORDS: Breast neoplasms; neoplasm staging; prognosis; nutritional status; obesity; hyperglycemia.

\section{RESUMO}

Objetivo: Analisar a associação do estado nutricional e glicemia de jejum com os principais fatores prognósticos tumorais no câncer de mama invasivo em mulheres submetidas a tratamento cirúrgico. Métodos: Estudo retrospectivo com mulheres maiores de 18 anos, diagnosticadas com câncer de mama invasivo, admitidas para tratamento cirúrgico no Hospital de Câncer III — Instituto Nacional de Câncer José Alencar Gomes da Silva. As variáveis coletadas foram: idade, Índice de Massa Corporal (IMC), comorbidades (hipertensão arterial sistêmica e diabetes mellitus), quimioterapia neoadjuvante, estado menopausal, glicemia de jejum, estadiamento clínico e marcadores tumorais (Receptor de Estrogênio e Progesterona/Her-2/Ki 67). Os dados categóricos foram expressos pela frequência e percentual e os dados numéricos pela média e desvio padrão. A análise estatística foi realizada por meio dos testes de: Kruskal-Wallis, Mann-Whitney, x2 de Pearson e Sperman. P-valores <0,05 foram considerados estatisticamente significantes. Resultados: 166 pacientes participaram da pesquisa. A média de idade foi de 59,1 ( $\pm 12,4)$ anos e a média de glicemia de jejum foi 109,5 $\pm 23,7 \mathrm{mg} / \mathrm{dL}$. De acordo com o IMC, $62,1 \%$ da amostra foi classificada com excesso de peso. O IMC elevado estava associado à presença de hipertensão e hiperglicemia, e não foi observada associação com fatores prognósticos. A hiperglicemia estava relacionada com idade mais avançada, maior comprometimento linfonodal, receptor hormonal positivo e estado pós-menopausal. Conclusão: O estado nutricional classificado pelo IMC não foi associado com fatores prognósticos no câncer de mama, sugerindo a necessidade de outros métodos antropométricos complementares para melhor diagnóstico nutricional. PALAVRAS-CHAVE: Neoplasias da mama; estadiamento de neoplasias; prognóstico; estado nutricional; obesidade; hiperglicemia.

IInstituto Nacional de Câncer José Alencar Gomes da Silva - Rio de Janeiro (RJ), Brazil.

*Corresponding author: tamires_rsc@hotmail.com

Conflict of interests: nothing to declare.

Received on: 04/08/2018. Accepted on: 07/13/2018 


\section{INTRODUCTION}

Breast cancer is the most common type of cancer in women around the world, representing $25 \%$ of all cases worldwide and $29.5 \%$ in Brazil. It is the most frequent tumor among the female population in all regions of the country, except the North, and the leading cause of death by cancer in developing countries. ${ }^{1}$

Breast neoplasia is multifactorial, involving biological-endocrine factors, reproductive life, aging, family history of breast cancer, high breast tissue density (ratio between glandular and breast adipose tissues), behavior, and lifestyle. In addition, alcohol consumption, overweight, a sedentary lifestyle, and exposure to ionizing radiation are potential agents for its development. Its prevention requires lifestyle changes; approximately $30 \%$ of breast cancer cases could be avoided with the practice of regular physical activity, a healthy diet, and body weight control. ${ }^{1}$

The World Health Organization considers obesity one of the major public health problems in the world. The estimate is that, in 2025, around 2.3 billion adults will be overweight, and more than 700 million, obese. Obesity is the excessive accumulation of body fat in an individual and has multifactorial causes. ${ }^{2}$ In addition to its relationship with hypertension, diabetes, and other chronic non-communicable diseases, it is associated with the development of 13 types of cancer, including post-menopause breast cancer. ${ }^{3}$ Overweight and obesity in breast cancer patients are connected with a worse prognosis and clinical outcome. ${ }^{4}$

According to the International Agency for Research on Cancer (IARC), the carcinogenesis process involves biological mechanisms linked to overweight, such as hyperinsulinemia, insulin resistance, changes in the metabolism of sex hormones, positive regulation of insulin-like growth factors, chronic inflammation, changes in immune function and adipokine production, vascular growth factors produced by fat tissue, and oxidative stress. ${ }^{3}$

Some studies have indicated certain causes for a worse clinical outcome in obese breast cancer patients, such as: association with other comorbidities, more advanced stage at diagnosis, unfavorable tumor characteristics, faster growth of tumor tissue due to deficient cellular immunity, pro-inflammatory state, and hormonal influences, among them high levels of estrogen and insulin. ${ }^{5}$

Some anthropometric measures can quantify body overweight, such as Body Mass Index (BMI), calculated by dividing weight in kilograms $(\mathrm{kg})$ by height in meters $(\mathrm{m})$ squared, $\mathrm{kg} / \mathrm{m}^{2}$. BMI is the most widely used method to evaluate body adiposity for being simple, practical, without cost, and a good indicator to classify obesity. ${ }^{6}$

Studies have been developed on the relationship between BMI and prognostic factors in breast cancer. ${ }^{7} \mathrm{~A}$ prognostic factor is a marker associated with overall survival, and a parameter of the clinical course, involving the risk of recurrence or death. Its study allows a more specific analysis of tumor behavior according to its progression, and better development of adjuvant therapy. ${ }^{8}$
Prognostic factors in breast neoplasm are classified in consonance with the patient's condition and tumor aspects. The main prognostic factors related to tumor are: histological type, degree of differentiation, size, presence of hormone receptors and tumor markers, and lymph node involvement. Regarding the host, the prognostic factors are: age at diagnosis, family history, BMI, and nutritional status, in addition to other not well-established genetic traits. ${ }^{9}$

Tumor size associated with the condition of axillary lymph nodes are the two most important prognostic indicators of breast cancer and comprise the basis of the TNM staging, established by the Union for International Cancer Control. Tumor size is directly related to the risk of recurrence and lymph node involvement, that is, smaller tumors have a better prognosis of both overall survival and disease-free survival. ${ }^{10}$

The histological grade reflects the malignant potential of the tumor, indicating its higher or lower metastasis capacity, and, when combined with the stage of the disease, it can improve the prediction of the outcome. ${ }^{11}$ Age is also an important prognostic factor in breast cancer. Despite the divergences found in several studies, most investigations highlight that patients in the age group 40-59 years have the best prognosis. On the other hand, young women ( $<35$ years) and those with more advanced age ( $>75$ years) have the worst prognosis..$^{12,13}$

Hormone receptors (HR) are proteins that bind to circulating hormones, mediating their cellular effects. Estrogen receptors (ER) and progesterone receptors (PR) are the HR most studied in breast cancer. Approximately two-thirds of breast carcinomas are HR-positive (ER and/or PR). This positivity is highly associated with a more favorable prognosis and a better response to hormone therapy when compared to patients with HR-negative tumors. ${ }^{13}$

The Human Epidermal Growth Factor Receptor 2 (HER2) is a biomarker also used as a prognostic factor. Its overexpression is related to a greater biological aggressiveness of the tumor and resistance to some types of treatment. HER2 encodes a membrane protein of tumor cells, which makes them develop faster and increases their duplication, resulting in more aggressive tumors. ${ }^{14}$

Ki-67 is also a well-studied biomarker and known as a prognostic factor. It is a nuclear protein expressed in proliferating cells and absent in resting cells. Its use as a cell proliferation marker showed that the higher its index (\%), the greater the cell proliferation and the lower the patient survival. Ki-67 can be used to divide patients into groups with good or bad prognosis. ${ }^{15}$

Studies suggest that high fasting blood glucose is also related to tumor growth and worse prognosis of breast cancer due to the association between hyperglycemia and various metabolic changes. ${ }^{16,17}$

Knowledge about the correlation between nutritional status and the main prognostic factors in breast cancer patients 
provides a better understanding of the population treated and the establishment of a more effective nutritional approach. Therefore, the main objective of this study was to analyze this association in women undergoing surgical treatment at Cancer Hospital III (INCA III).

\section{METHODS}

\section{Study design}

Observational, cross-sectional, retrospective study with patients admitted to oncological surgery at the Mastology Center of INCA III from October to December 2016.

\section{Eligibility criteria}

Female patients aged 18 years or older, diagnosed with invasive breast cancer and admitted to the surgical wards of INCA III for curative treatment.

\section{Exclusion criteria}

Women undergoing late reconstruction, palliative surgery, and/ or who lacked information in their hospital records.

\section{Data Collection}

For data collection, we used Admission Forms developed by the Nutrition Service of the same institution and electronic medical records. The variables collected were:

- Age: the number of complete years from the date of birth to the date of admission. Patients over 60 years of age were classified as older adults;

- Comorbidities: systemic arterial hypertension (SAH) and diabetes mellitus (DM);

- Current clinical staging: extension of malignant neoplasm determined by the Union for International Cancer Control (UICC), through a system called TNM Classification of Malignant Tumors (tumor size, lymph node involvement, metastasis, and grade); ${ }^{18}$

- Anthropometry: weight and height measured at the time of admission and BMI classification according to the $\mathrm{WHO}^{2}$ for adults and the $\mathrm{PAHO}^{19}$ for older adults;

- Fasting blood glucose: verified through a biochemical test performed in the preoperative routine at INCA III. The result was collected from the electronic medical record on the day of admission. We adopted the following parameters: $<100 \mathrm{mg} / \mathrm{dL}$ (normal blood glucose), 100-125 mg/dL (impaired glucose tolerance), and $\geq 126 \mathrm{mg} / \mathrm{dL}$ (diabetes mellitus); $;{ }^{20}$

- Tumor markers: presence or absence of hormone receptors (estrogen and progesterone), and expression of HER2 and \%Ki-67;

- Menopausal status: status of pre- or post-menopause reported at the time of hospitalization.

\section{Statistical analysis}

The data collected were analyzed anonymously with the software Statistical Package for Social Sciences, version 22.0.

The description of the sample used frequency and percentage as categorical variables and mean and standard deviation as numeric variables. We used the Kruskal-Wallis and Mann-Whitney tests to compare means in two or more groups, Pearson's $\chi^{2}$ test to associate two categorical variables, and Spearman's correlation coefficient to perform linear associations between two numerical variables, considered statistically significant when $\mathrm{p}<0.05$.

\section{Ethical aspects}

The Committee for Ethics in Research (CER) of INCA III approved this study under the number CAAE 73374417.3.0000.5274.

\section{RESULTS}

Among the 287 patients admitted, 166 were selected by the eligibility criteria of the study.

The mean age of the women under study was 59.1 \pm 12.4 years, ranging from 31 to 92 years, with half of the sample population consisting of older adults; $80.7 \%$ reported being in post-menopause. With respect to fasting blood glucose, $62 \%$ of the patients were in the classification above $99 \mathrm{mg} / \mathrm{dL}$, with a mean of $109.5 \pm 23.7 \mathrm{mg} / \mathrm{dL}$. Regarding anthropometric variables, the mean BMI was $28.9 \pm 5.8 \mathrm{~kg} / \mathrm{m}^{2}$. Tables 1 and 2 present the sample characteristics related to clinical, anthropometric, and tumor variables.

Table 3 shows the association of mean BMI and fasting blood glucose with the main tumor prognostic factors in breast cancer. We found no association between the mean BMI and prognostic factors. Women with higher mean fasting blood glucose had a significantly more advanced age, greater lymph node involvement, progesterone and estrogen receptor positive, and were in post-menopause.

When evaluating the association between BMI categories and comorbidities, we found that most hypertensive patients were obese $(51.1 \%)(\mathrm{p}<0.05)$. Diabetic patients did not show this association (Table 4). Table 5 indicates that patients with higher blood glucose levels had greater mean BMI.

No significant difference was observed between the mean fasting blood glucose of patients who underwent neoadjuvant chemotherapy $(112.7 \pm 28.6 \mathrm{mg} / \mathrm{dL})$ and those who did not $(106.9 \pm 18.6 \mathrm{mg} / \mathrm{dL})$.

The analysis of BMI categories and prognostic factors of the entire sample showed no significant association. An analysis stratifying the sample according to menopausal status presented no significant difference between groups.

The mean Ki- 67 of the total sample was $34.1 \pm 26.1 \%$, and when correlated with BMI and fasting blood glucose, it did not show a significant relationship. 


\section{DISCUSSION}

The findings of this study related to tumor characteristics indicated that $80.7 \%$ of the patients analyzed had ER-positive tumors, similar to data presented by Anderson et al., which revealed that more than $75 \%$ of all breast cancer cases have this tumor characteristic. ${ }^{21}$ The literature demonstrates that tumors with HER2 overexpression or amplification affect around $15 \%$ of patients with invasive cancer; ${ }^{12}$ in this sample, $13.9 \%$ of women had HER2 positive. The mean Ki-67 of the present study was $34.1 \%$. A standard cut-off point for the Ki-67 index has not been established due to the different methodologies used, ranging from 3.5 to $34 \%$, but these cut-off points are inconclusive. Ki-67 is an important predictor of neoadjuvant or adjuvant treatment, and the higher its index (\%), the greater the cell proliferation and lower the survival. The literature reveals that healthy breast cells have Ki-67 lower than $3 \%{ }^{15}$

Age at diagnosis is also an important prognostic factor. In this study, half of the sample consisted of older adults ( $>60$ years)

Table 1. Clinical, demographic, and anthropometric characteristics of women with invasive breast cancer.

\begin{tabular}{|c|c|c|}
\hline Variable & $\mathbf{n}$ & $\%$ \\
\hline \multicolumn{3}{|l|}{ Age } \\
\hline$\leq 39$ & 12 & 7.2 \\
\hline $40-49$ & 28 & 16.9 \\
\hline $50-59$ & 43 & 25.9 \\
\hline $60-69$ & 51 & 30.7 \\
\hline$\geq 70$ & 32 & 19.3 \\
\hline \multicolumn{3}{|c|}{ Neoadjuvant chemotherapy } \\
\hline Yes & 74 & 44.5 \\
\hline No & 92 & 55.5 \\
\hline \multicolumn{3}{|l|}{ Hypertension } \\
\hline Yes & 90 & 54.2 \\
\hline No & 76 & 45.8 \\
\hline \multicolumn{3}{|l|}{ Diabetes Mellitus } \\
\hline Yes & 27 & 16.3 \\
\hline No & 139 & 83.7 \\
\hline \multicolumn{3}{|l|}{ BMI classification } \\
\hline Underweight & 14 & 8.4 \\
\hline Normal & 49 & 29.5 \\
\hline Overweight & 38 & 22.9 \\
\hline Obesity & 65 & 39.2 \\
\hline \multicolumn{3}{|l|}{ Blood glucose level } \\
\hline Up to $99 \mathrm{mg} / \mathrm{dL}$ & 63 & 38.2 \\
\hline $100-125 \mathrm{mg} / \mathrm{dL}$ & 81 & 49.1 \\
\hline$\geq 126 \mathrm{mg} / \mathrm{dL}$ & 21 & 12.7 \\
\hline
\end{tabular}

BMI: body mass index. and $24 \%$ were up to 50 years of age, similarly to literature data, which show that approximately $50 \%$ of breast cancer cases occur in 65-year-old women or older, ${ }^{22}$ and $20 \%$ in women younger than 50 years of age. ${ }^{12}$

In the present study, according to BMI, over half of the sample $(62.1 \%)$ had excess weight (39.2\% overweight and $22.9 \%$ obesity). Hankó-Bauer et al. found this same scenario when they analyzed obesity in women with breast cancer, revealing that $62.45 \%$ of the sample were overweight and obese (33.07 and $29.38 \%$, respectively). ${ }^{10}$

The number of cases of overweight and obesity is increasing around the world. In Brazil, 50.5\% of women are overweight, ${ }^{23}$ which suggests that it is common for women with breast cancer also to be overweight. Obesity is associated with both an increased risk of developing breast cancer and worse prognosis of the disease, but their relationship is also complex..$^{12}$ Studies

Table 2. Distribution of invasive breast cancer patients according to tumor characteristics.

\section{Variable}

n

$\%$

Tumor size

\begin{tabular}{l|c|c}
\hline $\mathrm{T} 1(\leq 2 \mathrm{~cm})$ & 65 & 39.2 \\
\hline $\mathrm{T} 2(2-5 \mathrm{~cm})$ & 62 & 37.3 \\
\hline $\mathrm{T} 3(>5 \mathrm{~cm})$ & 16 & 9.6 \\
\hline $\left.\mathrm{T} 4{ }^{*}\right)$ & 23 & 13.9 \\
\hline
\end{tabular}

Lymph node involvement

\begin{tabular}{c|c|c}
\hline N0 & 87 & 52.4 \\
\hline N1 & 51 & 30.7 \\
\hline N2 & 24 & 14.5 \\
\hline N3 & 04 & 2.4 \\
\hline
\end{tabular}

Metastasis

\begin{tabular}{c|c|c}
\hline Yes & 01 & 0.6 \\
\hline No & 165 & 99.4 \\
\hline
\end{tabular}

Grade

\begin{tabular}{c|c|c}
\hline G1 & 23 & 13.8 \\
\hline G2 & 75 & 45.2 \\
\hline G3 & 68 & 41
\end{tabular}

Estrogen receptor

\begin{tabular}{l|c|c}
\hline Positive & 134 & 80.7 \\
\hline Negative & 32 & 19.3 \\
\hline Progesterone receptor & 123 & 74 \\
\hline Positive & 43 & 26 \\
\hline Negative & 23 & 13.9 \\
\hline HER2 & 143 & 86.1 \\
\hline Positive &
\end{tabular}

*Tumor of any size with skin or chest wall invasion. 
show that the main hypothesis is that excess fat tissue promotes a hormonal imbalance, and increases insulin and circulating insulin-like growth factor (IGF-1); and that adipocytes producing pro-inflammatory factors, such as tumor necrosis factor (TNF), interleukin, and C-reactive protein, induces the progression of the cell cycle and apoptosis inhibition, raising the risk of developing cancer. In addition, the factors mentioned might promote overexpression of oncogenes, ${ }^{24}$ oxidative stress, and changes in immune function. ${ }^{3}$

In the current study, we analyzed the relationship between nutritional status and prognostic factors and found no significant association between BMI and tumor size, lymph node

Table 3. Association of fasting blood glucose and body mass index (BMI) with prognostic factors in women with invasive breast cancer.

\begin{tabular}{|c|c|c|c|c|c|c|}
\hline \multirow{2}{*}{ Variable } & \multicolumn{3}{|c|}{ BMI } & \multicolumn{3}{|c|}{ Fasting Blood Glucose } \\
\hline & $\mathbf{N}$ & Mean士SD & p-value & $\mathbf{N}$ & Mean $\pm S D$ & p-value \\
\hline \multicolumn{7}{|c|}{ Age (years) } \\
\hline$\leq 39$ & 12 & $26.89 \pm 4.07$ & \multirow{5}{*}{0.58} & 12 & $97.25 \pm 8.04$ & \multirow{5}{*}{0.01} \\
\hline $40-49$ & 28 & $29.30 \pm 6.50$ & & 28 & $109.21 \pm 33.31$ & \\
\hline $50-59$ & 43 & $29.40 \pm 5.93$ & & 43 & $106.65 \pm 21.01$ & \\
\hline $60-69$ & 51 & $29.22 \pm 5.80$ & & 51 & $112.57 \pm 20.96$ & \\
\hline$\leq 70$ & 32 & $28.12 \pm 5.91$ & & 32 & $113.25 \pm 24.43$ & \\
\hline \multicolumn{7}{|c|}{ Tumor size } \\
\hline T1 & 65 & $28.38 \pm 6.12$ & \multirow{4}{*}{0.63} & 65 & $110.25 \pm 24.54$ & \multirow{4}{*}{0.78} \\
\hline $\mathrm{T} 2$ & 62 & $29.34 \pm 5.73$ & & 62 & $108.06 \pm 17.81$ & \\
\hline T3 & 16 & $27.90 \pm 4.88$ & & 16 & $102.50 \pm 9.79$ & \\
\hline T4 & 23 & $29.86 \pm 6.12$ & & 23 & $116.09 \pm 37.83$ & \\
\hline
\end{tabular}

Lymph node involvement

\begin{tabular}{|c|c|c|c|c|c|}
\hline NO & 87 & $29.17 \pm 5.67$ & \multirow{4}{*}{0.43} & 87 & $107.36 \pm 20.34$ \\
\hline N1 & 51 & $28.16 \pm 6.15$ & & 51 & $107.02 \pm 20.02$ \\
\hline N2 & 24 & $29.29 \pm 6.33$ & & 24 & $118.21 \pm 35.52$ \\
\hline N3 & 4 & $30.19 \pm 2.82$ & & 4 & $135.25 \pm 31.05$ \\
\hline
\end{tabular}

Metastasis

\begin{tabular}{|c|c|c|c|c|c|c|}
\hline No & 165 & $28.90 \pm 5.87$ & \multirow{2}{*}{0.94} & 165 & $109.56 \pm 23.77$ & \multirow{2}{*}{0.72} \\
\hline Yes & 1 & 29.31 & & 1 & 99.00 & \\
\hline \multicolumn{7}{|l|}{ Grade } \\
\hline G1 & 23 & $29.06 \pm 5.23$ & \multirow{3}{*}{0.79} & 23 & $106.61 \pm 18.39$ & \multirow{3}{*}{0.36} \\
\hline G2 & 75 & $29.12 \pm 5.80$ & & 75 & $112.84 \pm 28.64$ & \\
\hline G3 & 68 & $28.60 \pm 6.17$ & & 68 & $106.78 \pm 18.55$ & \\
\hline \multicolumn{7}{|c|}{ Menopausal status } \\
\hline Рre & 32 & $28.45 \pm 6.40$ & \multirow{2}{*}{0.58} & 32 & $103.00 \pm 18.57$ & \multirow{2}{*}{0.02} \\
\hline Post & 134 & $29.01 \pm 5.73$ & & 134 & $111.04 \pm 24.58$ & \\
\hline \multicolumn{7}{|c|}{ Progesterone receptor } \\
\hline Positive & 123 & $29.36 \pm 5.89$ & \multirow{2}{*}{0.11} & 123 & $111.64 \pm 24.96$ & \multirow{2}{*}{0.01} \\
\hline Negative & 43 & $27.59 \pm 5.61$ & & 43 & $103.35 \pm 18.60$ & \\
\hline \multicolumn{7}{|c|}{ Estrogen receptor } \\
\hline Positive & 134 & $29.09 \pm 5.89$ & \multirow{2}{*}{0.52} & 134 & $110.89 \pm 24.20$ & \multirow{2}{*}{0.03} \\
\hline Negative & 32 & $28.09 \pm 5.69$ & & 32 & $103.66 \pm 20.88$ & \\
\hline \multicolumn{7}{|l|}{ HER2 } \\
\hline Negative & 143 & $28.86 \pm 5.84$ & \multirow{2}{*}{0.65} & 143 & $110.44 \pm 24.94$ & \multirow{2}{*}{0.4} \\
\hline Positive & 23 & $29.16 \pm 6.06$ & & 23 & $103.61 \pm 12.61$ & \\
\hline
\end{tabular}

SD: standard deviation. 
involvement, metastasis, histological grade, hormone receptors, HER2, and Ki-67. These results differ from those of other studies that, after associating obesity with prognostic factors, revealed that overweight women with breast cancer had larger tumors and lymph node involvement. ${ }^{10,25,26}$ Daling et al., while studying the relationship between BMI and tumor markers in 1,177 NorthAmerican women with invasive breast cancer, found that those who were in the highest BMI quartile had larger tumors, higher histological grade, estrogen receptor negative, and more significant expression of Ki-67, when compared to women with tumor who were in the first BMI quartile. ${ }^{27}$

Currently, there are several anthropometric measures to assess excess fat in individuals. Among them, BMI is the most widely used method to classify overweight or obesity in adult populations for being simple, fast, and easy to apply and measure. However, when compared to methods that assess body composition, BMI shows an imprecise estimate of fat and lean mass. Some authors have questioned its use in diagnosing body fat. ${ }^{28}$

In this study, we did not adopt other anthropometric variables to analyze body fat distribution, such as waist circumference (WC) and waist-hip ratio (WHR). A Brazilian study by Felden and Figueiredo investigated the relationship between body fat distribution and breast cancer patients and revealed that women with WC $>88 \mathrm{~cm}$ were 2.08 times more likely to develop the disease than those with normal measures, not finding an association of BMI and WHR with breast cancer. ${ }^{29} \mathrm{~A}$ research conducted in the same institution with 2040 women with breast cancer, who had a profile similar to the participants in the current study, indicated that patients with greater abdominal fat (WC and WHR) had larger tumors and lymph node involvement; and, after analyzing the BMI and prognostic factors, it found no significant difference. ${ }^{30}$ These findings could suggest that abdominal obesity is more significant when analyzing the relationship between overweight and prognostic factors in breast cancer than assessing overall obesity.

Regarding comorbidities, more than half of the sample (54.2\%) had SAH. According to the Ministry of Health, 25.7\% of the population has this pathology. The relationship between hypertension and breast cancer is still inconsistent in the literature. A study revealed that hypertension before a breast cancer diagnosis was associated with worse survival, particularly for African-American women. ${ }^{31}$ The results of studies with animal models and humans suggest that hypertension can increase the carcinogenic response and initiate the carcinogenesis process. However, further studies are necessary to understand this association. ${ }^{32}$

Among the women participating in this research, $16.3 \%$ had diabetes mellitus, corroborating a study conducted in Mexico with a sample of 265 invasive breast cancer patients, in which $15 \%$ were diabetic. ${ }^{16}$ In the present study, despite the low percentage of diabetic patients, over half of the sample (62\%) presented pre-surgical hyperglycemia (blood glucose level $>99 \mathrm{mg} / \mathrm{dL}$ ). Among non-diabetic patients, 51.8\% had blood glucose level between 100 and $125 \mathrm{mg} / \mathrm{dL}$, belonging to the category of increased risk for the development of this comorbidity, and $4.3 \%$ had blood glucose level $\geq 126 \mathrm{mg} / \mathrm{dL}$, classified in the indicator of diabetes mellitus category, according to the American Diabetes Association. ${ }^{18} \mathrm{~A}$ recent study with women with breast cancer found higher blood glucose and insulin levels in nondiabetic patients. ${ }^{33}$

The present study showed a significant association between hyperglycemia and more advanced age, higher lymph node involvement, hormone receptor positive, and post-menopausal status. These results are in line with a similar study, conducted in the same institution, which revealed that women with fasting blood glucose above $100 \mathrm{mg} / \mathrm{dL}$ in the preoperative period had

Table 5. Association between fasting blood glucose and body mass index (BMI) of women with invasive breast cancer.

\begin{tabular}{l|c|c} 
Fasting blood glucose & BMI (Mean \pm SD) & p-value \\
$\leq 99 \mathrm{mg} / \mathrm{dL}$ & $27.6 \pm 5.04$ & \\
\hline $100-125 \mathrm{mg} / \mathrm{dL}$ & $29.9 \pm 5.09$ & 0.03 \\
\hline$\geq 126 \mathrm{mg} / \mathrm{dL}$ & $28.6 \pm 7.13$ & \\
\hline
\end{tabular}

SD: standard deviation.

Table 4. Association between body mass index (BMI) and comorbidities of women with invasive breast cancer.

\begin{tabular}{|c|c|c|c|c|c|}
\hline \multirow[b]{2}{*}{ Variable } & \multicolumn{5}{|c|}{ BMI } \\
\hline & $\begin{array}{c}\text { Underweight } \\
\text { (\%) }\end{array}$ & $\begin{array}{l}\text { Normal } \\
(\%)\end{array}$ & $\begin{array}{c}\text { Overweight } \\
(\%)\end{array}$ & $\begin{array}{l}\text { Obesity } \\
\text { (\%) }\end{array}$ & p-value \\
\hline \multicolumn{6}{|l|}{ Hypertension } \\
\hline No $(n=76)$ & 10.5 & 31.6 & 32.9 & 25.0 & \multirow{2}{*}{0.03} \\
\hline Yes $(n=90)$ & 6.7 & 27.8 & 14.4 & 51.1 & \\
\hline \multicolumn{6}{|c|}{ Diabetes Mellitus } \\
\hline No $(n=76)$ & 7.9 & 28.8 & 23.7 & 39.6 & \multirow{2}{*}{0.86} \\
\hline Yes $(n=90)$ & 11.1 & 33.3 & 18.5 & 37.0 & \\
\hline
\end{tabular}


larger tumors and lower survival. ${ }^{30}$ Villarreal-Garza identified decreased survival in patients with hyperglycemia - diabetic or not -, and a higher risk of death for women with serum glucose levels greater than $130 \mathrm{mg} / \mathrm{dL} .{ }^{16}$ Studies indicate an association of hyperglycemia with a worse prognosis of breast cancer and larger tumors. ${ }^{16,17}$ According to Erickson et al., hyperglycemia can directly influence the progress and outcomes of breast cancer through several mechanisms, including high levels of insulin and insulin-like growth factors, sex hormones, and inflammatory markers. ${ }^{17}$

Similarly to our results, a study performed with women with breast cancer in Southern Brazil did not identify a significant association of menopausal status with tumor characteristics and anthropometric variables. ${ }^{29}$

The current findings show that nutritional status, classified according to BMI, had no association with prognostic factors. These results might suggest the need for other complementary anthropometric methods, such as waist circumference and waisthip ratio, for a better nutritional diagnosis. Nonetheless, patients with fasting hyperglycemia had a more advanced age, higher lymph node involvement, hormone receptor positive, and postmenopausal status. Considering that overweight and hyperglycemia are modifiable risk factors, we can adopt new practices to improve nutritional intervention.

\section{REFERENCES}

1. Instituto Nacional de Câncer José Alencar Gomes da Silva. Coordenação de Prevenção e Vigilância. Estimativa 2018: Incidência de Câncer no Brasil. Rio de Janeiro: Instituto Nacional de Câncer José Alencar Gomes da Silva, Coordenação de Prevenção e Vigilância; 2017.

2. World Health Organization. Obesity: preventing and managing the global epidemic. Report of a WHO Consultation. WHO Technical Report Series (894). Geneva: World Health Organization; 2000.

3. World Cancer Research Fund; American Institute for Cancer Research. Food, nutrition, physical activity, and the prevention of cancer: a global perspective. Washington, D.C.: American Institute for Cancer Research; 2007.

4. Rock C, Doyle C, Demark-Wahnefried W, Meyerhardt J, Courneya K, Schwartz A, et al. Nutrition and physical activity guidelines for cancer survivors. CA Cancer J Clin. 2012;62(4):243-74. https://doi.org/10.3322/caac.21142

5. Carmichael A. Obesity as a risk factor for development and poor prognosis of breast cancer. Int J Obstetr Gynaecol. 2006;113(10):1160-6. https://doi.org/10.1111/j.1471-0528.2006. 01021.x

6. Associação Brasileira para o Estudo da Obesidade e da Síndrome Metabólica. Diretrizes brasileiras de obesidade. $4^{\mathrm{a}}$ ed. São Paulo: Associação Brasileira para o Estudo da Obesidade e da Síndrome Metabólica; 2016.

7. Kamineni A, Anderson M, White E, Taplin S, Porter P, BallardBarbash R, et al. Body mass index, tumor characteristics, and prognosis following diagnosis of early-stage breast cancer in a mammographically screened population. Cancer Causes Control. 2013;24(2):305-12. https://doi.org/10.1007/s10552012-0115-7

8. Diana C, Diana E, Alzamora N, Vilanova A, Climent J, Albaladejo C. Factores pronósticos del cáncer de mama. Modelo predictivo. Rev Oncol. 2004;6(8):472-82. https://doi. org/10.1007/BF02713084

9. Batschauer A. Avaliação hemostática e molecular em mulheres com câncer de mama receptor hormonal negativo [dissertação]. Belo Horizonte: Faculdade de Fármácia, Universidade Federal de Minas Gerais; 2009.
10. Hankó-Bauer O, Georgescu R, Coros M, Boros M, Barsan I, Stolnicu S. Correlation between obesity and prognostic/ predictive parameters with emphasis on the importance of lymph node metastases in patients with invasive breast carcinoma. Pol J Pathol. 2017;68(1):33-9. https://doi. org/10.5114/pjp.2017.67613

11. Makki J. Diversity of Breast Carcinoma: Histological Subtypes and Clinical Relevance. Clin Med Insights: Pathol. 2015;8:2331. https://dx.doi.org/10.4137\%2FCPath.S31563

12. Picon-Ruiz M, Morata-Tarifa C, Valle-Goffin J, Friedman E, Slingerland J. Obesity and adverse breast cancer risk and outcome: Mechanistic insights and strategies for intervention. CA: Cancer J Clin. 2017;67(5):378-97. https://doi.org/10.3322/ caac. 21405

13. Abreu E, Koifman S. Fatores Prognóstico no câncer de mama feminina. Rev Bras Cancerol. 2002;48(1):113-31.

14. Buitrago F, Uemura G, Sena MCF. Fatores prognósticos em câncer de mama. Com Ciências Saúde. 2011;22(Sup. 1):S69-82.

15. Pathmanathan N, Balleine R. Ki67 and proliferation in breast cancer. J Clin Pathol. 2013;66(6):512-6. https://doi.org/10.1136/ jclinpath-2012-201085

16. Villarreal-Garza C, Shaw-Dulin R, Lara-Medina F, Bacon L, RiveraD, Urzua L, etal.Impact of Diabetes and Hyperglycemia on Survival in Advanced Breast Cancer Patients. Experim Diabetes Res. 2012;2012:1-8. http://dx.doi.org/10.1155/2012/732027

17. Erickson K, Patterson R, Flatt S, Natarajan L, Parker B, Heath D, et al. Clinically Defined Type 2 Diabetes Mellitus and Prognosis in Early-Stage Breast Cancer. J Clin Oncol. 2011;29(1):54-60. https://doi.org/10.1200/JCO.2010.29.3183

18. Instituto Nacional de Câncer José de Alencar Gomes da Silva. TNM: classificação de tumores malignos. $6^{\mathrm{a}}$ ed. Rio de Janeiro: Instituto Nacional de Câncer José de Alencar Gomes da Silva; 2004. 254p.

19. Organização Pan-Americana de Saúde. Informe preliminar da

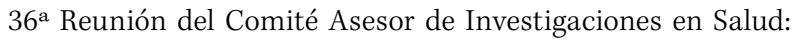
Encuesta Multicéntrica - Salud Bienestar y Envejecimento (SABE) en América Latina y el Caribe. Organização PanAmericana de Saúde; 2002. 
20. American Diabetes Association. Standard of Medical Care in Diabetes - 2017. Diabetes Care. 2017;40 (Supl. 1).

21. Anderson W, Chatterjee N, Ershler W, Brawley O. Estrogen Receptor Breast Cancer Phenotypes in the Surveillance, Epidemiology, and End Results Database. Breast Cancer Res Treat. 2002;76(1):27-36.

22. Gennari R, Curigliano G, Rotmensz N, Robertson C, Colleoni $\mathrm{M}$, Zurrida S, et al. Breast carcinoma in elderly women. Cancer. 2004;101(6):1302-10. https://doi.org/10.1002/cncr.20535

23. Brasil. Ministério da Saúde. Secretaria de Vigilância em Saúde. Departamento de Vigilância de Doenças e Agravos não Transmissíveis e Promoção da Saúde. Vigitel Brasil 2016: vigilância de fatores de risco e proteção para doenças crônicas por inquérito telefônico: estimativas sobre frequência e distribuição sociodemográfica de fatores de risco e proteção para doenças crônicas nas capitais dos 26 estados brasileiros e no Distrito Federal em 2016. Brasília: Ministério da Saúde; 2017.

24. Barros A, Barros M. HER e câncer de mama: inter-relações biológicas, prognósticas e terapêuticas. São Paulo: Roche; 2006.

25. Loi S, Milne R, Friedlander M, McCredie M, Giles G, Hopper J, et al. Obesity and Outcomes in Premenopausal and Postmenopausal Breast Cancer. Cancer Epidemiol BiomarkersPrev.2005;14(7):1686-91.https://doi.org/10.1158/ 1055-9965.EPI-05-0042

26. Rosenberg L, Czene K, Hall P. Obesity and poor breast cancer prognosis: an illusion because of hormone replacement therapy? Brit J Cancer. 2009;100(9):1486-91. https://dx.doi. org/10.1038\%2Fsj.bjc.6605025
27. Daling J, Malone K, Doody D, Johnson L, Gralow J, Porter P. Relation of body mass index to tumor markers and survival among young women with invasive ductal breast carcinoma. Cancer. 2001;92(4):720-9.

28. Nunes R, Clemente E, Pandini J, Cobas R, Dias V, Sperandei $\mathrm{S}$, et al. Confiabilidade da classificação do estado nutricional obtida através do IMC e três diferentes métodos de percentual de gordura corporal em pacientes com diabetes melito tipo 1. Arq Bras Endocrinol Metab. 2009;53(3):360-7. http://dx.doi. org/10.1590/S0004-27302009000300011

29. Felden J, Figueiredo A. Distribuição da gordura corporal e câncer de mama: um estudo de caso-controle no Sul do Brasil. Ciência Saúde Coletiva. 2011;16(5):2425-33. http://dx.doi. org/10.1590/S1413-81232011000500011

30. Gioseffi C. Relação da adiposidade central e glicemia de jejum com características tumorais e sobrevida global em mulheres com câncer de mama [dissertação]. Rio de Janeiro: Centro de Ciências da Saúde, Universidade Federal do Rio de Janeiro; 2017.

31. Tammemagi C, Nerenz D, Neslund-Dudas C, Feldkamp C, Nathanson D. Comorbidity and Survival Disparities Among Black and White Patients With Breast Cancer. JAMA. 2005;294(14):1765-72. https://doi.org/10.1001/jama.294.14.1765

32. Zhu Q, Xu W, Tao M. Biomarkers of the Metabolic Syndrome and Breast Cancer Prognosis. Cancers. 2010;2(2):721-39. https://dx.doi.org/10.3390\%2Fcancers2020721

33. Ferroni P, Riondino S, Laudisi A, Portarena I, Formica V, AlessandroniJ, et al. Pretreatment insulin levels as a prognostic factor for breast cancer progression. Oncologist. 2016;21:10419. https://doi.org/10.1634/theoncologist.2015-0462 